\title{
Merthyr Mawr: a case study for the assessment of nitrate at humid dunes in England and Wales
}

\author{
M.I Whitman, G. Farr, P.S. Jones, J. Schutten \& A, Papaioannou
}

1 Environment Agency, Coverdale House, Aviator Court, Amy Johnson Way, Clifton Moor, YO30 4GZ, UK

2 British Geological Survey, Columbus House, Tongwynlais, Cardiff CF15 7NE, UK

3 Natural Resources Wales, Maes y Ffynnon, Penrhosgarnedd, Bangor LL57 2DW, UK

4 Scottish Environment Protection Agency, Strathallan House, The Castle Business Park, Stirling FK9 4TZ, UK

5 WSP | Parsons Brinckerhoff, The Pump House, Shrewsbury SY12DP, UK

\begin{abstract}
Humid dunes in the UK are at risk from nutrient pressures from multiple sources. The Water Framework Directive 2000/60/EC (WFD) requires assessment and identification of these pressures with appropriate measures defined to mitigate against further damage. We discuss the application of nitrate threshold values for the WFD classification, illustrating this with a case study at Merthyr Mawr, South Wales, where ephemeral groundwater discharge from a spring ('Burrows Well') sourced within the Carboniferous Limestone, creates a large dune slack. Ecological surveys suggest that the vegetation in this slack was in unfavorable condition, due to high levels of nitrate. Applying the source-pathway-receptor model an investigation was undertaken to improve the conceptual model and assess the significance of damage from groundwater derived nutrients. Results show groundwater nitrate $\sim 10 \mathrm{mg} / \mathrm{l}$ as $\mathrm{N}$ feeding the main slack waters. The vegetation survey data shows clear evidence of ecological damage, and the hydrogeological data traces the source of this back to the Carboniferous Limestone aquifer and not the overlying blown sands. Discharging groundwater is the source of the enrichment. Isotopic analysis shows that the $\mathrm{N}$ is derived from inorganic fertiliser and atmospheric $\mathrm{N}$. During the first cycle WFD characterisation the unfavorable status of the dunes due to chemical groundwater pressure resulted in a failure of the surrounding groundwater body, which was designated as poor status. The site has been re assessed for the 2nd Cycle WFD characterisation where recently developed nitrate 'threshold' values have been applied to assess the significance of damage for groundwater derived nutrients. The surrounding Carboniferous Limestone catchment is complex and could not be sufficiently constrained, thus land management changes could not be targeted. The paucity of historical or repeat vegetation surveys limits our ability to measure change within the dune vegetation and causes difficulties in understanding the impact of multiple pressures.
\end{abstract}

\section{Introduction}

The Water Framework Directive 2000/60/EC (WFD) requires classification of groundwater bodies as either good or poor for both chemical and quantitative status. The status of each groundwater body is determined by six tests, one of which assesses the qualitative and quantitative groundwater related pressures on groundwaterdependent terrestrial ecosystems (GWDTE). This test assesses whether a GWDTE has been significantly damaged by either poor water quality or insufficient quantity of water from a groundwater body (GWB) upon which it is directly dependent. If the wetland is significantly damaged by a groundwater mediated pressure, then the surrounding groundwater body will be designated as poor status (Whiteman et al. 2010) and a programme of measures is required. This paper describes the WFD classification process and the application of nitrate threshold values to GWDTE, specifically the investigation of significant damage at humid dune sites. We illustrate this with a case study and discuss knowledge gaps and lessons learned from a detailed WFD investigation.

During each six year River Basin Cycle, a screening process has been followed in the UK for each GWDTE to determine the risk of ecological damage. European Union guidance (CIS Guidance No. 12, European 
Commission, 2003) states that the expression 'significant damage' is based upon the magnitude of the damage and the ecological or socio-economic significance of the terrestrial ecosystem. Schutten et al. (2011) explain that the magnitude of the damage is related to whether the GWDTE continues to have the capacity to fulfill its ecological or socio-economic function. For those GWDTE that belong to the Natura 2000 network, the failure to meet agreed conservation targets (e.g. Davy et al, 2006; 2010) can be interpreted as significant damage for the WFD groundwater status assessment. This parallel approach would imply that if the conservation targets of the Natura 2000 area cannot be met as a result of chemical or quantitative anthropogenic pressures on the GWB and there is a groundwater hydraulic or pollutant linkage, the GWB should be considered 'at risk' (during characterisation) or at poor status (during status assessment). It is worth noting that the risk assessment looks forward to the end of the next River Basin Management Plan (RBMP) cycle, and status assessment looks back at performance during the last RBMP cycle.

One way of estimating the degree of damage is to answer the following questions (Whiteman et al. 2010):

1. How do the surrounding groundwater pressures change the hydrological conditions beneath the wetland (e.g. water levels and/or contaminant concentrations)?

2. How strong is the connection between hydrological conditions in the underlying aquifer (s) and the wetland?

3. How do the hydrological conditions in the wetland affect the ecology, i.e. is there evidence of ecological damage?

In the UK, a series of eco-hydrological guidelines have been developed which define generic environmental supporting conditions for plant communities contained in specific habitats, including coastal humid dunes (Davy et al. 2006; Davy et al. 2010). In order to apply the WFD classification test (UKTAG, 2012a), it is necessary to determine, on a site-specific basis, the required environmental supporting conditions (e.g. flows, levels and chemistry) for the groundwater-dependent plant communities.

If the required environmental supporting conditions are not met within a coastal humid dune, for example because a chemical nutrient threshold has been exceeded, we may expect to see adverse impacts upon the wetland. In general, higher nature conservation value is given to wetlands characteristic of low nutrient settings. These wetlands tend to be associated with a high species diversity per unit area, and in general support more rare species than wetlands in higher nutrient settings (UKTAG, 2012). In a lowland context, low nutrient wetlands are particularly highly valued because they are rare. Experience shows that these lowland sites are particularly vulnerable to nutrient enrichment. Changing nutrient conditions, and in particular enrichment, can change the relative competitive ability of individual plant species and can result in:

- degradation or complete loss of high value species and communities;

- a change of plant communities within the wetland;

- increasing dominance of particular plant species that are responsive to elevated levels of nutrients (e.g. common reed, nettle); and

- $\quad$ changes in the structure of particular plant communities (such as reedbeds) that affect their function as a habitat for birds or insects.

As a result of these changes, nutrient enrichment can affect the conservation interest and condition of the wetland (JNCC, 2004), and thereby can influence the status of the groundwater body (as described above).

The timing and duration of the nutrient pressure is important. For example, a short-lived phosphate peak that travels through a wetland during biologically inactive times, such as in winter, might have limited impact, whilst the same or smaller pressure during the growing season can have a significant effect (UKTAG, 2012). Nitrate can also be removed from a wetland through de-nitrification in soil. The effectiveness of this process depends on the oxidation state of the soil and temperature as it is mediated via bacteria (Mayer et al, 2007).

Groundwater generally travels slowly. This means that a nutrient plume can last for a long period of time, especially as most nitrate and phosphate in groundwater comes from diffuse sources. In addition, high nutrient levels identified in a groundwater body may not yet have reached the GWDTE and therefore the nutrient pressure on the GWDTE may increase over time.

There are a number of different factors which affect the significance of nutrient exceedance, including the fate of the nutrient in the wetland, residence time, chemical pathways and ecological response times (UKTAG, 2012). The sensitivity of wetlands to nutrients can also be affected by vegetation and water management regimes, The reversibility of impact has to be considered, as it very difficult (and costly) to reverse the impact of 
nutrients on wetlands. Once a nutrient pressure has changed the species composition of plant communities, or in the case of phosphate become embedded in the biomass, it will be near impossible to change. This non-linear relationship between pressure and state is well documented for lakes and is equally applicable to wetlands.

The aims of this study were to:

1. Use the results of the GWDTE risk assessment, classification and review of monitoring methods (Brooks et al. 2009) to establish a small number of targeted risk-based investigations on GWDTEs in England and Wales. The Merthyr Mawr study site was one of the sites targeted and was selected because there was a high risk of significant damage, but insufficient existing monitoring information to test whether the outcome of the risk assessment was consistent with the situation on the ground.

2. Establish infrastructure, methods and monitoring, the results from which can be used to review the effectiveness of measures on GWDTEs in River Basin Management Plans, and to prevent deterioration in status.

3. Undertake monitoring for at least one annual hydrological cycle to establish a baseline ecological monitoring/condition assessment, quantitative monitoring and chemical monitoring, with emphasis on identifying the simplest, most cost-effective techniques and rapid condition assessments, for example using walkover surveys.

\section{Materials and Methods}

\subsection{Source-pathway-receptor approach}

The risk assessment for coastal humid dunes was based on the source-pathway-receptor (S-P-R) approach (Figure 1). The source (S) is an abstraction or source of chemical pollution that can enter the water cycle, the pathway $(\mathrm{P})$ is the transmission route e.g. groundwater, rainfall or surface water and the receptor is the vegetation within the GWDTE. Farr et al. (2014) describe the methods of monitoring and investigation at GWDTE which are used in this paper. Brooks et al. (2009) describe the tiered process of development of conceptual models at GWDTE. Davy et al. 2006 outlined a generic conceptual model for water supply mechanisms to humid coastal dunes, with Wetland Water Supply Mechanisms or 'Wetmecs' (see Wheeler et al. 2009; Whiteman et al. 2009 for explanation of Wetmecs) (Figure 1).

\subsection{Vegetation mapping}

In the United Kingdom plant communities are characterised using the National Vegetation Classification (NVC) system (Rodwell, 1991-2000). The most recent NVC survey at Merthyr Mawr was undertaken in 1995, and since there were some doubts about site condition status and trends, a bespoke vegetation survey was undertaken for this study based on the methodology of Wheeler et al. (1999)which utilises recording from fixed quadrats, but with a reduced species data set sufficient to detect change in vegetation composition and to enable interpretation of vegetation change in terms of change in environmental conditions, such as dehydration or nutrient enrichment. The aim of this survey was to link changes to the vegetation communities to the presence of any nutrient enrichment in groundwater entering the site. Professional knowledge and research information was used to determine which wetland plant communities were critically dependent on groundwater (UKTAG, 2004).

Targeted vegetation surveys were undertaken to characterize the effects of nutrient enrichment (Schlumberger Water Services, 2010). Three plots were established at Merthyr Mawr, comprising of a square 12 x $12 \mathrm{~m}$ plot within which $360.5 \mathrm{~m} \times 0.5 \mathrm{~m}$ quadrats are recorded in on a stratified random sample design. The same quadrat, originally random, distribution was used for all plots to reduce confusion when the plots are repeated at a later date. Other similar investigations picked out key indicator species to detect nutrient enrichment, for example at fen sites, however the potential impacts of changes in ground water quality and quantity in particular from Burrows Well were believed to be less predictable on this site in part as a consequence of natural habitat succession on the system. As a consequence no attempt was made to pick out any key indicator species, instead all vascular plants within each quadrat were recorded. Lower plants were simply divided into the following broad groupings: terricolus macro-lichens, thalloid liverworts, leafy liverworts, acrocarpous mosses and pleurocarpus mosses. Species groupings were recorded simply on the basis of presence with only plants rooted within the quadrat recorded (Schlumberger Water Services, 2010). 
The quadrats for the ecological survey plots were chosen during a site visit on $14^{\text {th }}$ September 2009 by representatives from the Countryside Council for Wales (now Natural Resources Wales) and their locations are shown in Figure 3. Plot 1 was established within vegetation directly downstream from Burrows Well. This vegetation appeared to be nutrient enriched, being dominated by Phalaris arundinacea with docks, nettles and thistles all prominent. The intention of the plot was to demonstrate the degree of nutrient enrichment. Barring successional changes a rapid response to any reduction in the nutrient load is considered to be unlikely without radical management intervention to strip the existing nutrients. Plot 2 was established in an area of relatively good quality humid dune slack outside the likely area of influence from Burrows Well, the ephemeral spring that supplies water to the slack. The slack is particularly important as one of the key locations for the Annex II species Petalophyllum ralphsii although as a consequence of habitat succession this liverwort is becoming increasingly confined to areas of damp open ground along footpaths. Plot 3 was established in an area of open dune slack at the limit of the most obvious area of influence from Burrows Well. This area floods to a significant depth in most winters so the area is at risk from high nutrient groundwater. Ecological surveying of the plots was completed by Grace O’Donovan through EDP Ltd. in September 2009.

\subsection{Groundwater chemistry}

\subsubsection{Groundwater chemistry}

The water chemistry data presented for the case study site was undertaken at the Environment Agency 'National Laboratory' accredited to ISO 17025. Water chemistry was sampled from boreholes, dipwells, springs and slack waters. Dipwells and boreholes were purged using a 12V submersible pump prior to sampling. A standardised minimum sample suite (Table 1) was used for samples obtained on site. Analysis includes major ions used to type groundwater (e.g. $\mathrm{Na}^{+}, \mathrm{K}^{+}, \mathrm{Mg}^{2+}, \mathrm{Ca}^{2+}, \mathrm{Na}^{+}, \mathrm{K}^{+}, \mathrm{Cl}^{-}, \mathrm{SO}_{4}{ }^{2-}$ and $\mathrm{HCO}_{3}{ }^{2-}$ ), field parameters; (temperature ${ }^{\circ} \mathrm{C}$, electrical conductivity $\mu \mathrm{s} / \mathrm{cm}$, dissolved oxygen $\%, \mathrm{pH}$ and $\mathrm{Eh} \mathrm{mv}$ ), and nutrients (nitrate $\mathrm{mg} / \mathrm{l} \mathrm{N}$, phosphate mg/l). All analysis was undertaken at the Environment Agency 'National Laboratory' accredited to ISO 17025.

\subsubsection{Age dating and isotopes}

Chlorofluorocarbons (CFCs) and sulphur hexafluoride $\left(\mathrm{SF}_{6}\right)$ can be used to age relatively young groundwater up to 50 years old and provide indications on the extent of groundwater mixing and the likely groundwater flow mechanisms (Gooddy et al., 2006). Using a submersible 12V pump a single unfiltered sample was collected from outflow at Burrows Well (11 ${ }^{\text {th }}$ March 2010). Using a displacement method (Oster et al. 1996) to avoid atmospheric contact the sample was stored in two glass bottles contained within metal cans. Analysis was undertaken at the British Geological Survey with $\mathrm{CFCs}_{\text {and }} \mathrm{SF}_{6}$ measured by gas chromatography with an electron capture detector after pre-concentration by cryogenic methods, based on the methods of Oster et al. (1996) and Busenberg and Plummer (2000).

Nitrogen and oxygen isotopic composition $\left(\boldsymbol{\delta}^{\mathbf{1 5}} \mathrm{N}_{\mathrm{NO}}\right.$ and $\left.\boldsymbol{\delta}^{\mathbf{1 8}} \mathbf{O}_{\mathrm{NO}}\right)$ of dissolved $\mathrm{NO}_{3}$ were determined at four locations; Burrows Well (SS8565077260), Borehole MM1 (SS8560276878), Dipwell D4 (SS8625276696) and Candleston Spring (SS8713477157). Samples were collected in triplicate and filtered through a $0.45 \mu \mathrm{m}$ pore size filter. Samples were collected using a submersible pump on the $5^{\text {th }}$ February 2010 and analysis was undertaken at the University of East Anglia following the process according to according to Sigman et al. (2001) and Casciotti et al. (2002).

\subsection{Development of nitrate 'threshold values' for wetland habitats in the UK}

Threshold values are needed for WFD assessment, to determine what groundwater concentrations of chemicals, if exceeded, would indicate a pressure that could be (or actually is) causing damage to the GWDTE (UKTAG, $2012 b$ ). In practice the values are used during risk screening to trigger further investigation where needed. A combination of a damaged GWDTE (such as failure to meet conservation objectives) and exceedance of the relevant threshold values triggers further investigations (UKTAG, 2012b).

The first stage is to identify wetlands dependent upon groundwater and a list of 2,363 GWDTEs (including 70 sites with vegetation considered typical of humid dune slacks) were identified judged to be critically dependent on groundwater during the first cycle of the WFD in England and Wales, and further sites in Scotland. Chemical data associated with the GWDTEs all of which were designated under European (Special Areas of Conservation) or national legislation (Sites of Special Scientific Interest/ASSI) were analysed (UKTAG, 
2012b). A nitrate threshold value was developed for groundwater considered to be hydrogeologically connected to each wetland habitat, including humid dunes using three sources of information (UKTAG, 2012b), these were:

1. empirical correlation between wetland condition and chemistry data for hydrogeologically linked groundwater bodies across the UK;

2. $\quad$ site specific investigations, for example the case study within this paper; and

3. other published databases and literature.

Generic targets or threshold values for nitrates in wetland habitats in the UK were established for a range of habitats including humid dunes (UKTAG, 2012b).

\subsubsection{Correlation of wetland condition and chemical data}

\section{Empirical Correlation}

Threshold Values were produced using a statistical and rule-based approach which is described below and which we have used to identify how our observations fit with the UKTAG knowledge (UKTAG, 2012b). From the list of 2,363 GWDTEs in England and Wales, and further sites in Scotland, a total of 180 GWDTE were selected. For these sites there was high confidence in the degree of connectivity between the wetland and the groundwater body, This dataset includes groundwater chemical data for 13 wet dune sites (Davy et al. 2010, table D1 in Appendix D).

For each of the 180 identified GWDTE, WFD groundwater quality monitoring boreholes within $2 \mathrm{~km}$ were identified. The hydrogeological connection between the monitoring point and the GWDTE were evaluated, using local hydrogeological expertise. Where the WFD groundwater monitoring borehole was considered to be hydrologically linked to the GWDTE with a high degree of confidence, the water chemistry data for that location from the groundwater quality monitoring network was retrieved. 13 humid dune sites were considered to be hydrogeologically connected to a WFD groundwater monitoring borehole with a high degree of confidence. For each WFD groundwater monitoring site, the 6-yearly mean groundwater chemical concentrations were calculated, using data from the groundwater body classification in the first River Basin Management Plans. If 6-yearly mean values were not available, shorter quality assured datasets with a minimum of 3 years were used.

The condition of each GWDTE was measured using the relevant JNCC common Standards for Monitoring (JNCC, 2004), and was assessed through routine condition monitoring programmes carried out by the nature conservation organisations. Condition data were obtained through extracts of Natural England's and Natural Resources Wales' condition monitoring databases. Where a site was in favourable condition we have inferred that the groundwater is not currently causing significant damage. This is a conservative approach and it is possible that some GWDTEs are exposed to elevated nutrient levels, however this has not yet been reflected in ecological signs of enrichment.

For GWDTEs that were in good ecological condition, approximately two-thirds of the 180 sites included in the statistical analysis, mean and $75^{\text {th }}$ percentile concentrations were calculated for nitrate (as $\mathrm{N} \mathrm{mg/l)} \mathrm{in} \mathrm{the} \mathrm{WFD}$ groundwater monitoring point linked to the GWDTE. For the wet dune slacks within the dataset $(n=10)$ the mean concentration of nitrate as $\mathrm{N}$ was $2.7 \mathrm{mg} / \mathrm{l}$ and the $75^{\text {th }}$ percentile $5.0 \mathrm{mg} / \mathrm{l}$.

Approximately one-third of the 180 GWDTEs were classified as being in poor condition. For those wet dune slacks within the dataset in poor condition, the mean concentration for nitrate (as $\mathrm{N} \mathrm{mg} / \mathrm{l})$ was $7.7 \mathrm{mg} / \mathrm{l}(n=3)$. This classification is based upon sites with an unfavourable conservation status and where there is evidence to suggest nutrient impacts have contributed to this unfavourable condition.). The reason for unfavourable condition may not be as a result of poor groundwater quality, and other factors such as under or over grazing, atmospheric deposition and succession may contribute to unfavourable status.

\section{Site-specific investigations}

During the analysis, nitrate data from site-specific investigations were also collated for comparison with the data from the groundwater water quality monitoring networks used in the analysis above. For comparison the mean concentration of nitrates (as $\mathrm{N} \mathrm{mg/l)} \mathrm{for} \mathrm{humid} \mathrm{dune} \mathrm{slack} \mathrm{sites} \mathrm{in} \mathrm{good} \mathrm{condition,} \mathrm{from} \mathrm{site} \mathrm{specific}$ investigations in Scotland was $0.5 \mathrm{mg} / \mathrm{l}(n=2)$ and for sites in poor condition in Wales was $7.5 \mathrm{mg} / \mathrm{l}(n=3)$. Once the appropriate data was identified the mean and $25^{\text {th }}$ percentile were calculated for nitrate (as $\mathrm{N} \mathrm{mg/l}$ ). 


\section{Other databases}

Nitrate concentrations in dune slacks from other published databases and literature are considered by Davy et al. (2010) who propose the following guidelines, based on data from 12 sand dune sites in England, Wales and Scotland. Dipwells at relatively unimpacted UK dune systems suggest a 'reference condition' of Total Inorganic Nitrogen (TIN) concentrations $<0.20 \mathrm{mg} \mathrm{N} \mathrm{mg/l}$. On the basis of deviation from a UK reference condition, and on data from contaminated dipwells, Davy et al. (2010) suggested that dune groundwater concentrations $>0.20$ $\mathrm{mg} \mathrm{N} \mathrm{L}-1$ are unusual, concentrations $>0.40 \mathrm{~N} \mathrm{mg} / \mathrm{l}$ may indicate contamination, and concentrations $>1.0 \mathrm{~N}$ $\mathrm{mg} / \mathrm{l}$ indicate likely contamination and merit concern. However, the authors stress that these recommendations are not made on the basis of adverse impact, since little or no data are currently available from the UK to guidesuch recommendations. They also note that these concentrations are close to or below the detection limits for many routine water chemistry analyses by commercial companies.

The data from empirical correlation, site-specific investigations and other databases was combined to produce the Threshold Values (TVs) (UKTAG, 2012b) using the following rules:

1.The TVs must lie above the mean (per vegetation category) and preferably above the $75^{\text {th }}$ percentile for sites in good condition

2.The TVs must lie below the mean (per vegetation category) and preferable below the 25th percentile for sites in poor condition

3.The TVs must include the knowledge from the within site research

4.The TVs must reflect the available knowledge from the literature

5.The TVs are, where possible, a round number (or $1 / 2$ ) to reflect the uncertainty in the data

6.The TVs must include expert knowledge from the Wetland Task Team members

Logistic regression curves were plotted for each habitat type, for wet dune slacks (Figure 2) this shows how the likelihood of a GWDTE being in good condition decreases with increasing nutrient concentration in the groundwater that feeds the wetland and supports the determination of the actual values of the TV (as shown in rules 1-6 above) (UKTAG, 2012b). The open-bars along the top axis indicate the data distribution of GWDTE's in good condition and the solid bars along the bottom axis show the data distribution of GWDTE's in poor condition. The results of the logistic regression show that it is highly likely (85\% to 95\%) that the GWDTE is in good condition when the 'Threshold Value' is not exceeded. From Figure 2 it can be seen that the threshold for Wet Dunes is $2.5 \mathrm{mg} / \mathrm{l} \mathrm{N}$, rounded up to $3 \mathrm{mg} / \mathrm{l} \mathrm{N}$ following rule 5 above (equivalent to $13 \mathrm{mg} / \mathrm{NO}_{3}$ ).

\subsubsection{Overview of WFD assessment of dune sites in England and Wales}

A two-stage assessment was used by the Environment Agency for the wetland test in the WFD groundwater status assessments, firstly risk screening using the method outlined by Whiteman et al. (2010), followed by a site specific assessment using the UKTAG procedure for groundwater classification (UKTAG 2012a). 22 humid dune sites were assessed during the second River Basin cycle in England and Wales, following the procedure outlined above. Nine sites were assessed as below the threshold value $\left(13 \mathrm{mg} / \mathrm{l} \mathrm{NO}_{3}\right)$ and 13 sites were assessed as above the threshold value. However for 11 sites this conclusion was based upon the average monitored nitrate concentration for the WFD groundwater body as a whole, since there was no local chemical monitoring point within a $5 \mathrm{~km}$ radius of each site with high confidence of a good hydraulic connection between the groundwater body and the wetland. Two sites were assessed as exceeding the threshold value based upon measured groundwater chemical data from a borehole less than $2 \mathrm{~km}$ from the wetland with high hydrogeological confidence in the hydraulic connection between the groundwater body and the wetland. These results indicate that groundwater chemical pressures on dune slacks may be quite widespread, however confidence in the GWDTE test results are heavily constrained by sparse chemical monitoring data in the vicinity of the wetlands.

\subsection{Case study: Merthyr Mawr, South Wales, UK}

Merthyr Mawr is a large coastal humid dune slack system located about $5 \mathrm{~km}$ southwest of Bridgend, South Wales, UK (NGR SS860768) (Figure 3). Dune ridges and slacks dominate the topography of the 478 ha site. Inland the topography rises to a Carboniferous limestone plateau with incised dry valleys which trend towards 
the dunes. Merthy Mawr is managed by Natural Resources Wales (NRW) and is designated as a Special Area of Conservation (SAC) and a National Nature Reserve (NNR).

\subsection{Vegetation}

The Annex 1 habitats (EU Habitats Directive 92/43/EEC) include; 2190 Humid Dune Slacks, 2170 Dunes with Salix repens ssp.argentea (Salicion arenariae) and 2130 Fixed dunes with herbaceous vegetation or 'grey dunes'. These habitats all occur at the centre of the site and are at risk from elevated $\mathrm{N}$ in groundwater entering the site via the Burrows Well, where NVCs are more typical of MG11 (mesotrophic inundation grassland community) and S28 (fen type communities) than typical SD16 (dune slack communities). It is this difference that is perceived as impact from elevated nitrates in the slack groundwater. Eco-hydrological guidelines for wet dune habitats (Davy et al, 2010) highlight National Vegetation Communities (NVC) that are sensitive to changes in water levels including NVC SD13 to SD17, all of which are present at Merthyr Mawr.

An NVC survey in 1995 showed assemblages in the areas recently mapped appear to be similar, although no recent NVC map is available to confirm this. There is a visible and actual difference in vegetation downstream from Burrows Well, where the communities are more typical of MG11 (mesotrophic inundation grassland community) and S28 (fen type communities) than typical SD16 (dune slack communities). It is also possible that the outflow area has remained in this quasi steady state assemblage for some time, possibly decades, prior to 1995 . It is also unknown if the area ever actually exhibited a more typical dune slack community. A habitat survey covering Merthyr Mawr was also undertaken in 2001 by the Countryside Council for Wales (now part of Natural Resources Wales) (Figure 4).

\subsection{Ecological survey results}

Plot 1 (Q1 on Figure 3)

\section{Management}

There appears to be little active management at present in Plot 1. Sward height is very high within the plot and the area is scrubby with tall herb vegetation. Grazing appears to be absent in Plot 1 altogether.

\section{Vegetation Condition}

This plot is very species-poor (14 species in all) and is dominated by Phalaris arundinacea. There are other species indicative of disturbance such as Cirsium vulgare, Urtica dioica and Rumex crispus present. Sward height is high $(20-40 \mathrm{~cm})$, letting very little light through for other broad-leaved species to survive. No lower plant species such as bryophytes or lichens were found. The vegetation is more representative of fen vegetation than wet slack vegetation (Davy et al. 2006). It fits reasonably well with S28 Phalaris arundinacea tall herb fen (Davy et al. 2006).

\section{Plot 2 (Q2 on Figure 3)}

\section{Management}

There appears to be little active management at present, although there were signs of scrub removal nearby. Grazing appears to be quite light and by rabbits only, with some grasses and sedges chewed off. However, the sward height is generally much lower in Plot 2 compared to the other two plots.

\section{Vegetation Condition}

The vegetation is in good condition with a high species diversity (c. 46 species) compared to Plots 1 and 3 . The species composition is dominated by Salix repens and Rubus caesius. Other common species present were Thymus polytrichus, Holcus lanatus, Festuca rubra. There is some scrub development with young saplings of Betula pendula and Betula pubescens present. Pleurocarpous mosses were always present and in high cover (Pseudoscleropodium purum and possibly Brachythecium albicans). Some acrocarpous mosses were found where there was bare soil - probably Tortula spp. No liverworts were observed. Some patches of terricolous lichen were found (Cladonia cf rangiformis). There were also some small areas of bare earth present where rabbits may have been scraping. This vegetation is a good representative of a dry dune slack flora and fits 
well with SD 16 of the NVC (Salix repens-Holcus lanatus dune slack). The flora is characteristic of drier older dune slacks with some grazing pressure. It was less clear which sub-community the Plot belonged to but probably the Rubus caesius subcommunity, grading into the Ononis repens sub-community. There was evidence of scrub encroachment with the presence of Betula pubescens and B pendula in the quadrats, which leans more towards the Ononis repens sub-community.

Plot 3 (Q3 on Figure 3)

\section{Management}

There appears to be little active management at present in Plot 3. Grazing is quite light and by rabbits only, with some grasses and sedges chewed off. Sward height is intermediate between Plot 1 and Plot 2, ranging from 6-18 $\mathrm{cm}$.

\section{Vegetation Condition}

Plot 3 was a flat area surrounded by higher dunes in all directions. It was quite species poor compared to Plot 2 but also had a different species composition than the other two plots. Rubus caesius was dominant rather than Salix repens and there were only c. 11 species recorded in the whole plot. Agrostis stolonifera, Potentilla anserina and Carex arenaria were constant throughout. Ranunculus repens also had a higher presence here than in the other two Plots and Rumex cf. crispa was found occasionally too. Galium palustre was very occasionally present and also Mentha aquatica, suggesting that it is wetter at other times of the year. Conversely, there was an absence of any bryophyte flora. This may be an impoverished form of SD16 as it does not fit easily into any of the other SD slack communities. It may be subject to some form of disturbance.

\subsection{Geology}

Merthyr Mawr dunes are formed from Quaternary blown sand deposits, underlain by laterally extensive tidal flat clays and silts. The clay is $0.2 \mathrm{~m}$ thick (BH MM1) although it is not known how the clay deposit varies in thickness or in lateral extent. Gravel deposits occur at the base of the blown sands and dunes and have historically been commercially exploited (Wilson et al. 1990). The dunes are underlain by Carboniferous Friars Point Limestone Formation (Figure 5). The Friars Point Limestone Formation is a thin to thick bedded skeletal packstone with subordinate thin beds of shaley argillaceous skeletal packstones and mudstones. About $1 \mathrm{~km}$ to the north the limestone has been historically exploited at Tythegston Quarry, the empty quarry was then used as an unlined landfill in the 1970's. Extraction of limestone at the Cornelly Quarry about $2 \mathrm{~km}$ to the north west continues to the present day and has been the subject of detailed hydrogeological impact assessments that include the monitoring of discharge at the ephemeral 'Burrows Well' spring.

\subsection{Hydrogeology}

Dune slacks are the key wetland features, they are damp or wet hollows in the low points between dunes, characterised by seasonally fluctuating water levels. This can result in significant flooding in winter and spring, when water levels can reach $+50 \mathrm{~cm}$ above ground level, contrasting to groundwater levels as much as $200 \mathrm{~cm}$ below ground level (Davy et al 2010) during summer months. Hydrological requirements of specific dune slack vegetation communities were further refined by Curelli et al. (2011), who showed that only $40 \mathrm{~cm}$ separate the minimum water levels in the driest and wettest dune slack communities.

A generic hydrogeological conceptual model for a humid dune site is presented in Figure 1. The system at Merthyr Mawr comprises of two main hydrogeological units, the Carboniferous Limestone bedrock and the overlying Blown Sand deposits. Groundwater within the blown sands is influenced by the local dune topography and water in the majority of slacks is derived from this aquifer, sourced by recharge from direct rainfall. Groundwater in the Carboniferous Limestone aquifer is separated from the blown sand aquifer by a basal clay deposit of unknown lateral extent. Groundwater enters the site to the north via the ephemeral 'Burrows Well' spring forming the largest slack, outlined on Figure 1. It is this slack that is impacted by the high nitrate waters sourced from the Carboniferous Limestone aquifer, rather than slacks sourced from groundwater within the blown sand aquifer. The typical area of inundation into the dune slacks by discharge from Burrows Well spring is depicted in Figures 3 and 5. 
Water level dataloggers were installed to monitor hourly groundwater level at two shallow sand dipwells (D9 \& D11) and a borehole in the Carboniferous Limestone aquifer directly below the site (BH MM1) (Figure 5). Monthly manual water level data from dipwells D1 - D11 showed there is a hydraulic gradient from the centre of the site outwards (Schlumberger Water Services, 2010). This gradient is maintained year round, proving the presence of a groundwater 'mound' at the centre of the site. Groundwater level data from borehole MM1 (Water Management Consultants, 2008) are more variable $(0.97$ to $5.27 \mathrm{mbgl})$ than the shallow dipwells D9 (0.47 to $1.15 \mathrm{mbgl}$ ) and D11 (0.55 - $1.0 \mathrm{mbgl}$ ) (Figure 6). Larger changes in piezometric head in borehole MM1 reflect the low storage of the Carboniferous Limestone, and its rapid response to recharge events. Groundwater levels (borehole MM1) show a diurnal tidal response and a fortnightly tidal variation related to the tidal cycles within the adjacent Bristol Channel, however there is no evidence for saline intrusion below the site. The lower range of variation within the dipwells is not unexpected and reflects the higher storage in the dune sands, a smaller catchment and disconnection from a tidal influence. The underlying Carboniferous limestone aquifer has a much larger, and as of yet undefined catchment.

Between 2008 and 2010 the discharge from Burrows Well varied between zero and 230 1/s with the spring running dry, in April of each year, remaining dry until June in both 2008 and 2009 (Figure 6). Both 2008 and 2009 were wet years and it is likely that no-flow periods would be longer during 'normal' or drier years. Major rainfall events correlate with spring discharges, when the spring is flowing, accession starts almost immediately with a peak flow observed about two days later. Total annual flows from Burrows Well range from 2,100,000 $\mathrm{m}^{3}$ in 2008 to $1,435,800 \mathrm{~m}^{3}$ in 2009 with the outflow water forming a 3.59 ha slack. The water from this area will eventually recharge into the blown sand aquifer and flow towards the coast. The low permeability clay layer may separate the water from the underlying limestone aquifer, however it is possible that small gaps exist within the clay and could allow recharge to the Carboniferous Limestone aquifer. Using the geological and hydrogeological information collected as part of the WFD investigation a site-specific conceptual model is presented (Figure 1) depicting the inferred aquitard and monitoring dip-wells and borehole.

\subsection{Atmospheric nitrogen deposition}

The main perceived pressure facing the ecology of Merthyr Mawr are elevated nitrogen inputs, which can be derived from atmospheric loading and groundwater. The critical load for atmospheric nitrogen at dune slacks is $<10-12 \mathrm{~kg} \mathrm{~N} / \mathrm{ha} / \mathrm{yr}$ (Bobbink and Hettelingh, 2011) and this value was used by Jones et al. (2005) who determined a nitrogen budget for the site and estimated atmospheric loading of nitrogen at Merthyr Mawr to be at the lower end of the target value, c. $10 \mathrm{~kg} \mathrm{~N} / \mathrm{ha} / \mathrm{yr}$. The critical loads for $\mathrm{N}$ are unlikely to be exceeded by atmospheric deposition alone, however combination with $\mathrm{N}$ input from groundwater could result in an estimated inflow of $52 \mathrm{kgN}_{\text {day }}{ }^{-1}$ (Jones et al. 2005).

\subsection{Groundwater nitrate loading}

Hydrochemical analysis has been undertaken at Merthyr Mawr between 1998 and 2015 (Jones et al. 2005; Jones et al. 2006; Water Management Consultants 2008; Schlumberger Water Services 2010). Samples have been collected from dipwells and boreholes but primarily from the Burrows Well, the ephemeral spring that feeds the large slack.

\section{Limestone $v$ dune water}

There are two main groundwater systems, the underlying Carboniferous Limestone and the blown sand deposits. Groundwater chemistry can discriminate between them. Strontium is a key minor ion in determining the source of groundwater (Environmental Simulations International, 2004), and it is thought to be derived from aragonite in seashells within the dune sands. The result is that dune derived waters have a much higher Sr concentration (>400 ug/l) than the limestone derived groundwater (<200 ug/l).

Groundwater chemistry data (Table 2) show that groundwater from the Burrows Well and MM1 boreholes are of similar $\mathrm{Ca}-\mathrm{HCO}_{3}{ }^{-}$types suggesting a source within the Carboniferous Limestone aquifer. However nitrate levels are consistently higher in the limestone aquifer than they are within the dipwells (D4, D6, D9) installed within the blown sand aquifer, suggesting that the limestone aquifer is the principle source of N. Elevated $\mathrm{N}$ can 
occur locally within the dunes away from the main Burrows Well, and has been attributed to the clearance of scrub and subsequent breakdown of organic matter (Jones et al. 2006).

\section{Burrows Well}

Long term groundwater quality at Burrows Well (1998-2010) show that nitrate levels have an average value over this period of $8.3 \mathrm{mg} / \mathrm{l} \mathrm{N}$. In 2009, for example, concentrations ranged between 8.95 and $10.2 \mathrm{mg} / 1 \mathrm{NO} 3-\mathrm{N}$ (Figure 7). Nitrate loading within the slack created by groundwater discharge from Burrows Well can reach 44.2 $\mathrm{kg} \mathrm{N} / \mathrm{ha} / \mathrm{d}$ (Schlumberger Water Services, 2010). The catchment for the Burrows Well spring is not well defined, so it is currently hard to consider land management options to reduce nutrient input. The high contribution of atmospheric nitrate also complicates the matter further. The high nitrates, concentrated in the underlying limestone aquifer, are separated by the underlying clay. Nitrates enter the site via Burrows Well and the resulting slack area is indeed affected by the high nutrient loading, however the majority of the Merthyr Mawr site is not at risk from elevated nitrate input. Phosphates are also low and this is possibly a controlling or limiting factor.

\section{7 $\mathrm{CFC} \mathrm{SF}_{6}$ age dating and $\mathrm{N}$ and $\mathrm{O}$ isotopes}

\subsubsection{CFC SF 6}

$\mathrm{CFC}$ and $\mathrm{SF}_{6}$ can be used as tracers to provide recharge dates for young groundwater (Gooddy et al., 2006). The single sample collected form the Burrows Well provided results that are several times the modern signal; CFC$12 \mathrm{pmol} / 1$ 7.7; CFC-11 pmol/1 8.38 and SF6 fmol/1 7.11. These results indicate either an anthropogenic or indeed geogenic source of 'contamination' and no age of recharge could be calculated. No repeat test has been undertaken at the Burrows Well and future use of this result should be used with caution.

\subsection{2 $\delta^{15} \mathrm{~N}_{\mathrm{NO}}$ and $\delta^{18} \mathrm{O}_{\mathrm{NO}}$}

Nitrogen and oxygen isotopic composition of NO3 are expressed respectively as $\delta^{15} \mathrm{NNO}_{3} \delta^{18} \mathrm{ONO}_{3}$ from Burrows Well (7.6 \%o and 4.3 \%o), Borehole MM1 (10.6\%o and $6.3 \%$ ), Dipwell D4 (14.6 \%o and $15.2 \% 0$ ) and Candleston Spring (7.3\%o and $5.2 \%$ ). Analysis of the results by the University of East Anglia concluded that the primary source for the nitrate was via atmospheric nitrogen deposition and inorganic fertilisers, as opposed to septic tanks or animal manure. The contribution of nitrogen from atmospheric deposition indicates that controlling land use within the groundwater catchment may not be sufficient enough to reduce nitrogen entering the wetland. However the groundwater catchment for Burrows Well is poorly defined due to complex heterogeneity of the karstic aquifer and the knock on effect of this is that it is not currently possible to identification the land where over fertilization may be of concern.

\subsection{Conclusions of site investigation}

Nitrates are expected to be entering the groundwater through a mixture of diffuse sources upgradient of the site. The nitrate isotope analysis has shown the source of the nitrate to be associated with nitrification of soil inorganic nitrogen, originally sourced from atmospheric deposition and application of inorganic fertilisers. They do not show a clear link with large inputs from animal manure or septic tank leakage. There is little drift cover and the nutrients would quickly be able to enter the limestone aquifer.

Jones et al. (2005) concluded that groundwater levels were affected by both rainfall events and groundwater inflows. They also noted that groundwater levels did not respond immediately to the onset of flow at Candleston Spring and Burrows Well, indicating storage effects within the blown sands and a potential degree of compartmentalisation within the sands. It was also thought unlikely that there was a strong groundwater feed to certain areas of the site during the summer months as water levels were highly variable. Although the general observations of Jones et al. (2005) still hold true they are now explained by a different hydrogeological conceptual understanding for the site. It is now considered likely that the clay layer seen at the base of several of the dipwells and auger holes is acting as an aquitard between the sands and limestone. Further, it is believed that the quantity of groundwater seepage occurring along the base of the escarpment is therefore expected to be low. A conceptual model for the site is shown in Figure 1. 
The catchment to Burrows Well is karstic and is likely to prove difficult to determine with any accuracy. Whilst work using tracers may be a useful tool to map out flow paths these are likely to change through time and there is no guarantee that the true catchment could ever be determined. It cannot be assumed that the land adjacent to the sand dunes is the source of the high nitrates and the entire limestone block may have to be designated as the groundwater catchment. This may prove impractical if nitrate reduction measures are to be implemented.

The case study provides a clear example of damage related to a groundwater- derived source. There is clear evidence of damaged vegetation in plots 1 and 3 (those that are under influence of the Burrows Well spring) and no clear evidence of damage in plot 2 (not under the influence of the spring) which shows that the discharging groundwater is the source of the enrichment (atmospheric inputs are likely to be uniform across the site - Jones et al. 2005). The hydrogeological analysis shows that the nitrate enrichment is from the Carboniferous Limestone aquifer and not from the blown sands, and the Isotopic analysis shows that the nitrogen is derived from inorganic fertiliser and atmospheric nitrogen.

\section{Discussion}

\subsection{Ecological mapping}

One of the main knowledge gaps for this study was being able to quantify change in vegetation over time, leading to uncertainties about how potential pressures had impacted the site. There is a lack of repeated vegetation survey data which limited this analysis, especially within the nitrate enriched main slack and repeat NVC surveys would help support our understanding of change. It is also difficult to separate, or consider in combination, the potential drivers for changes in vegetation including; natural dune succession, atmospheric deposition and groundwater loading of $\mathrm{N}$.

\subsection{Threshold values}

We defined nitrate threshold values for broad habitat types such as wet dune slacks and applied them, however we recognize that they are based on limited data from the UK. We also recognize that on-site data from specific investigations of wet dune slacks is limited (Curelli et al. 2011; Rhymes et al. 2014) as are long term datasets.

We have not looked at phosphate data in detail to estimate the risk of ecological damage. The method for risk screening during the first River Basin cycle used phosphate as a measure of risk to the ecology, however further statistical analysis reported in UKTAG (2012b) found that the phosphate data was not considered useful to the interpretation of good or poor site condition due to multiple cross-correlations. Therefore, in the second River Basin cycle, the nitrate concentration in groundwater was instead used as a measure of risk to the ecology.

Research at Aberffraw dunes in south west Anglesey has specifically addressed groundwater N concentrations and impacts on the biological condition of the site (Rhymes et al. 2014). That study showed adverse impacts on vegetation composition at low levels of groundwater nitrate input, below current GWDTE guidelines for dune slacks. Given the link made in this analysis between nitrate concentrations and site condition, it is not surprising that the threshold value chosen for this study is higher than the concentration reported to indicate likely contamination by Davy et al. (2010) or Rhymes et al. (2014). The threshold value used in this study can be thought of as an indicator for the regulator to take action with defensible measures to reduce nitrate loadings in a catchment, rather than the lowest concentration at which negative ecological responses can be detected. Despite the limitations of this approach, the threshold values are believed to offer a practical tool for initial risk screening though we would find evidence based refinement to this approach valuable going forward.

\subsection{Conceptual model development and whole site approach / source apportionment}

Farr \& Hall (2014) stress that it is important to have an advanced hydrological conceptual model to quantify the loading of nitrate from groundwater and surface water pathways. The process of developing a hydrogeological conceptual model and testing it with field data is illustrated by Brassington \& Younger (2010). A poor understanding of the hydrology of any given site will result in knowledge gaps (e.g. Jones et al. 2005). Investigations at GWDTE often focus on either groundwater nutrients or atmospheric nutrients and we really 
need a whole system approach where all sources of $\mathrm{N}$ are monitored and source apportionment is carried out accordingly.

\section{Conclusions}

The Merthyr Mawr case study provides a clear example of chemical damage to a dune slack system related to a groundwater- derived source. An improved conceptual understanding has been gained, along with clear evidence of damaged vegetation in plots 1 and 3 (those that are under influence of the spring) and no clear evidence of damage in plot 2 (not under the influence of the spring) which show that the discharging groundwater is the source of the enrichment (atmospheric inputs are likely uniform across the site). The hydrogeological analysis shows that the $\mathrm{N}$ enrichment is from the Carboniferous Limestone and not from the blown sands, and the isotopic analysis shows that the $\mathrm{N}$ is derived from inorganic fertiliser and atmospheric $\mathrm{N}$.

Long-term time series of water quality data are crucial to any investigation into chemical impacts at GWDTE including wet dune slacks. We strongly support the need for data sharing between academic, regulatory and other bodies involved in making impact assessments at GWDTEs.

The Nitrate threshold values developed by UK-TAG (2012b) have been used for risk screening purposes during this study. There is a need to improve on these threshold values through collection of further chemical data from GWDTEs, along with site condition monitoring. Further statistical analysis is required, especially to understand the role of phosphates in limiting/causing ecological damage at GWDTEs.

We recommend further work be carried out on source apportionment of wetlands to determine the role of atmospheric deposition of nutrients, including nitrates: is this actually a larger problem than diffuse-point source aqueous nitrogen?

Vegetation mapping, using the NVC approach is vital to enable chemical pressures to be related to ecological change. Repeat NVC surveys are required, and can usefully be supplemented by targeted vegetation mapping as undertaken in this study.

\section{Acknowledgments}

The authors would like to thank the owners of the site, Merthyr Mawr Estates and the site manager, Duncan Ludlow and Scott Hand (Natural Resources Wales). Paul Inman (Independent Consultant) is thanked for the collection of groundwater level and chemistry data on behalf of Natural Resources Wales. We would also like to thank Tarmac Ltd and Mike Streetly of ESI Ltd for providing discharge data from the Burrows Well. Gareth Farr publishes with the permission of the executive director of the British Geological Survey, NERC. The views expressed in this article are those of the authors and not necessarily those of the Environment Agency, Natural Resources Wales or the Scottish Environment Protection Agency.

\section{References}

Bobbink, R. \& Hettelingh, J.P. (eds) 2011. Review and revision of empirical critical loads and dose response relationships. Proceedings of an expert workshop, Noordwijkerhout, 23-25 June 2010. Coordination Centre for Effects, RIVM, NL. www.rivm.nl/cce

Brassington, F.C. \& Younger, P.L. 2010. A proposed framework for hydrogeological conceptual modeling. Water \& Environment Journal, 24, 261-273.

Brooks, A., Brown, R. \& James, S. 2009. Guidance on monitoring and investigation at groundwater-dependent terrestrial ecosystems (GWDTE). Environment Agency of England \& Wales report GEHO1108-BOZG-E-E 
Casciotti, K.L., Sigman, D.M., Galanter Hastings, M., Bohlke, J.K and Hilkert, A. 2002. Analytical Chemistry 74: 4905-4912.

Countryside Council for Wales, 2008. Core Management Plan (including conservation objectives) for Kenfig/Cynffig SAC.

Curreli A, Wallace H, Freeman C, Hollingham M, Stratford C, Johnson H, et al. Eco-hydrological requirements of dune slack vegetation and the implications of climate change. Sci Total Environ 2012. 443: 910-9.

Davy, A.J., Grootjans, A.P., Hiscock, K., Peterson, J., 2006. Eco-hydrological guidelines for dune habitats Phase 1. English Nature Research Reports Number 696.

Davy A.J., Hiscock K.M., Jones M.L.M., Low R., Robins N.S., Stratford C. 2010. Ecohydrological guidelines for wet dune habitats, phase 2. Protecting the plant communities and rare species of dune wetland systems. Ecohydrological guidelines for wet dune habitats. GEHO0310BSGV-E-P. https://www.gov.uk/government/uploads/system/uploads/attachment_data/file/298034/geho0310bsgv-e-e.pdf

Environment Agency, 2009. Groundwater Quality Review: The Carboniferous Limestone of the Porthcawl Schwyll aquifer unit. Environment Agency Wales (unpublished).

Environmental Simulations International, 2004. The Cornelly Group of Quarries: Hydrogeological impact assessment for Cornelly Quarry and combined quarries. Consultant report for Tarmac Western Ltd.

European Commission, 2003. Common implementation strategy for the Water Framework Directive, Guidance Document No12. The role of wetlands in the Water Framework Directive. ISBN 92-894-6967-6.

Farr, G and Hall, J. 2014. Atmospheric deposition at groundwater dependent wetlands: implications for effective catchment management and Water Framework Directive groundwater classification in England and Wales. Nottingham, UK, British Geological Survey, 62pp. (OR/14/047) (Unpublished) http://nora.nerc.ac.uk/510750/

Farr, G., Whiteman, M. and Jones, P.S. 2014. Ecohydrological methods for the investigation of significant damage at groundwater dependant terrestrial ecosystems. In: IAH Ireland conference Proceedings 2014: The Role of Hydrogeology, Ireland, April 2014. British Geological Survey. http://nora.nerc.ac.uk/507428/

Gooddy, D, Darling, G, Abesser, C and Lapworth, D. J. 2006. Using chlorofluorocarbons (CFCs) and sulphur hexafluoride (SF6) to characterise groundwater movement and residence time in a lowland Chalk catchment. Journal of Hydrology, 330 (1-2). 44-52. 10.1016/j.jhydrol.2006.04.011

JNCC, (2004), Common Standards Monitoring Guidance for Lowland Wetland, Version August 2004, ISSN $1743-8160$

Jones, M.L.M, Pilkington, M.G, Healey, M, Norris, D.A, Brittain, S.A, Tang, Y.S. and Reynolds, B. 2005. Determining a nitrogen budget for Merthyr Mawr sand dune system. Final report for Countryside Council for Wales. CEH Project No: C02352NEW, CCW Contract No: FC 72-02-59. May 2005

Jones, M. L. M.; Reynolds, B.; Brittain, S. A.; Norris, D. A.; Rhind, P. M.; Jones, R. E., 2006. Complex hydrological controls on wet sand dune slacks: The importance of local variability. Science of the Total Environment, 372. 266-277.

Mayer, P.M., Reynolds, S.K., Marshall, Jr, McCutchen, D. and T.J. Canfield, 2007. Meta-analysis of nitrogen removal in riparian buffers. J. Environ. Qual. 36, 1172-1180.

Rodwell, J.S. (Ed.), 1991-2000. British Plant Communities, vols. 1-5. Cambridge University Press, Cambridge. 
Rhymes, J., Wallace, H., Fenner, N. and Jones, L, 2014. Evidence for sensitivity of dune wetlands to groundwater nutrients. Science of the Total Environment 490 (2014), 106 - 113.

Schutten, J, Verweij, W, Hall, A. \& Scheidleder, A. (2011). Common Implementation Strategy for the Water Framework Directive (2000/60/EC). Technical Report No.6 Technical Report on Groundwater Dependent Ecosystems. European Commission Technical Report - 2011- 056, December 2011. ISBN 978-92-79-21692-3.

Schlumberger Water Services, 2010. Report on targeted risk-based investigations on selected Welsh Groundwater Dependent terrestrial Ecosystems (Cors Bodeilio and Merthyr Mawr). Report for Environment Agency.

Sigman D. M., Casciotti, K. L., Andreani, M. Barford, C. Galanter M and Bohlke J. K. 2001. Analytical Chemistry 73: 4145-4153.

UKTAG (2012a). Paper 11b (i) Groundwater Chemical Classification for the purpose of the Water Framework Directive and the Groundwater Directive. Version Feb 2012.

http://www.wfduk.org/sites/default/files/Media/Assessing\%20the\%20status\%20of\%20the\%20water\%20environ ment/GWChemical\%20Classification_FINAL_2802121.pdf

UKTAG (2012b). Technical report on groundwater dependent terrestrial ecosystem (GWDTE) threshold values. Version 8 March 2012. http://www.wfduk.org/resources\%20/groundwater-dependent-terrestrialecosystemthreshold-values

Water Management Consultants, 2008. Groundwater Dependent Wetlands: Investigation and instrumentation of six Welsh wetland SSSIs. Consultant report 1-234 for Environment Agency Wales.

Wheeler, B.D., Shaw, S.C. \& Hodgson J.G. 1999. A monitoring methodology for wetlands. Report to Environment Agency, Peterborough.

Wheeler, B.D., Shaw, S.C., Tanner, K., 2009. A wetland framework for impact assessment at statutory sites in England and Wales. Environment Agency Science report SC030232/SR1.

Whiteman, M.I., Wheeler, B.D., Shaw, S.C., Lewis, T., Grout, M. \& Tanner, K., 2009. Use of WETMECS typology to aid understanding of groundwater-dependent terrestrial ecosystems in England and Wales. In: Quevauviller, P., Fouillac, A.M., Grath, J., Ward, R. (Eds.), Groundwater Quality Assessment and Monitoring. John Wiley \& Sons, pp. 259-272.

Whiteman, M., Brooks, A., Skinner, A., \& Hulme, P. 2010. Determining significant damage to groundwater dependant terrestrial ecosystems in England and Wales for use in implementation of the Water Framework Directive. Ecological Engineering, 36, p1118-1125.

Wilson, D, Davies, J R, Fletcher, C, and Smith, M, 1990, Geology of the South Wales Coalfield, Part vi: the country around Bridgend Memoir of the British Geological Survey, sheet 261 and 262 (England and Wales); 2nd edition; (1st ed. 1904) 


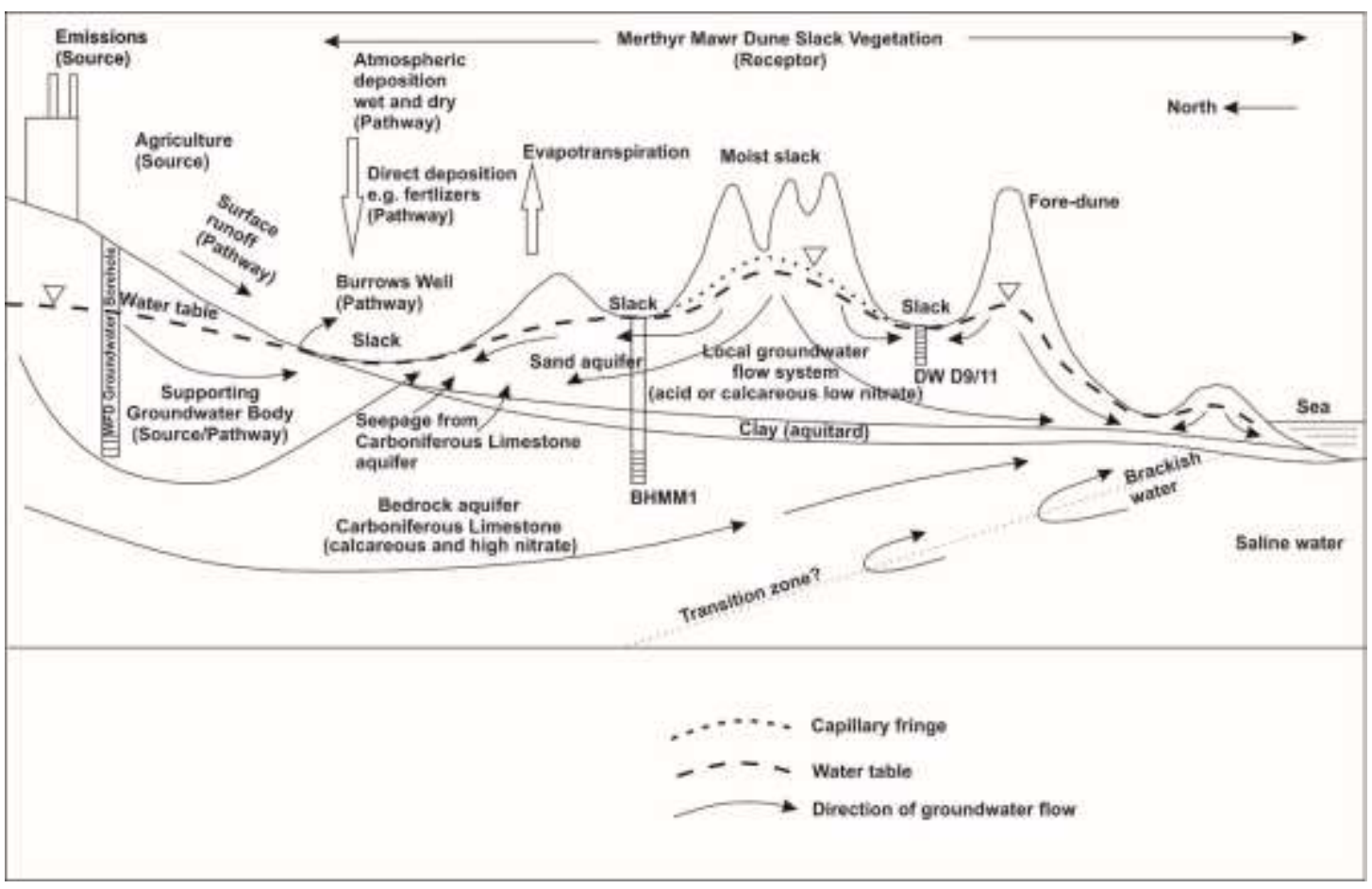

Figure 1. Conceptual model of hydrological and hydrogeological controls on humid dune slacks in coastal areas. Source (S), Pathway (P) and Receptors (R) are identified for nutrient pressures at humid dunes (after Davy et al 2006) this conceptual model is based upon Merthyr Mawr. 


\section{Wet Dune slack}

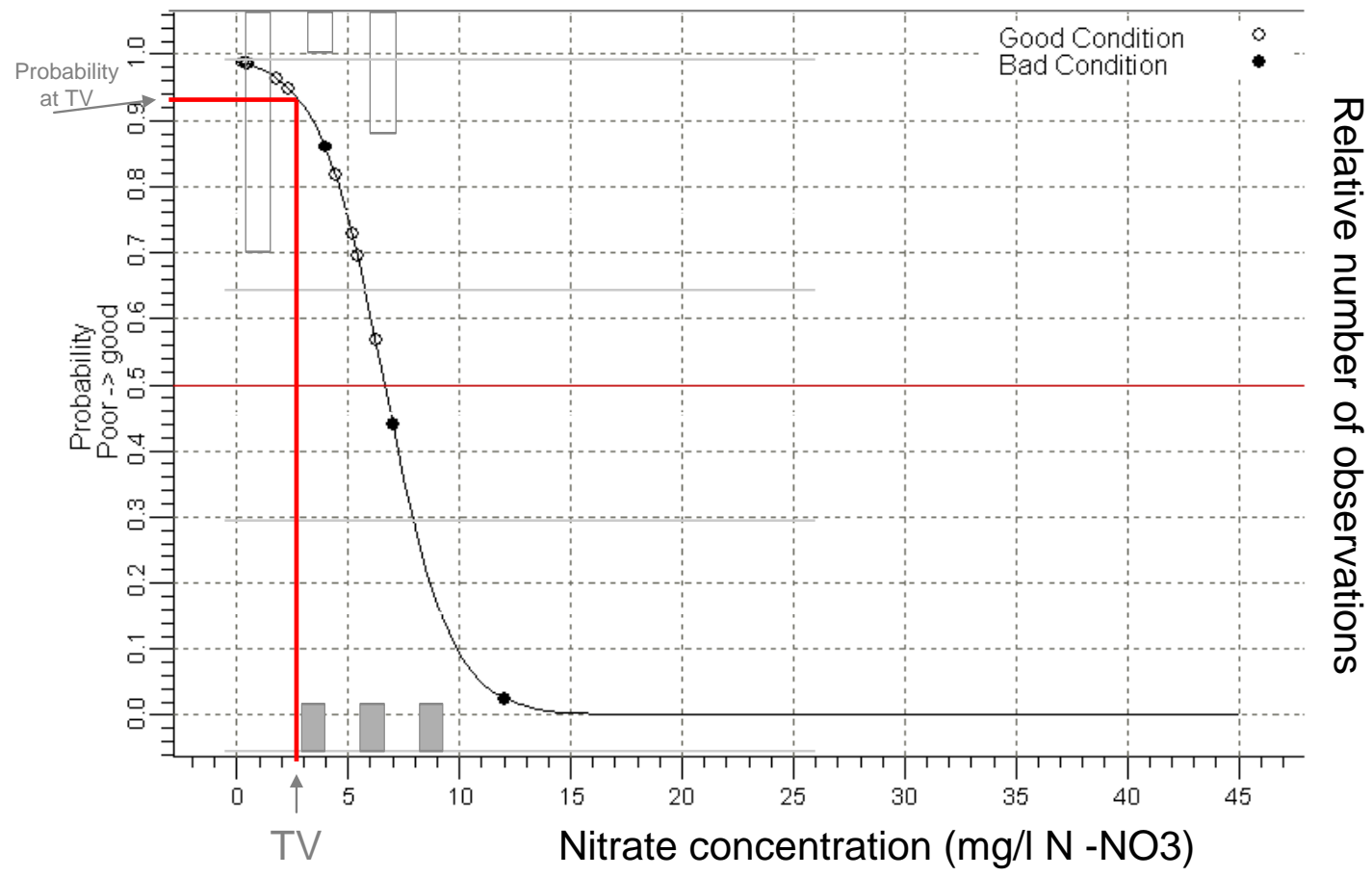

Figure 2. Logistic regressions showing the probability of a wet dune slack in good or bad condition wetland at a range of nitrate $\left(\mathrm{N}\right.$ as $\left.\mathrm{N}-\mathrm{NO}_{3}\right)$ concentrations. It also shows the derived threshold value and the data distribution of wet dune slacks in good (open bars along top) or poor condition (closed bars at bottom). (UKTAG, 2012b) 


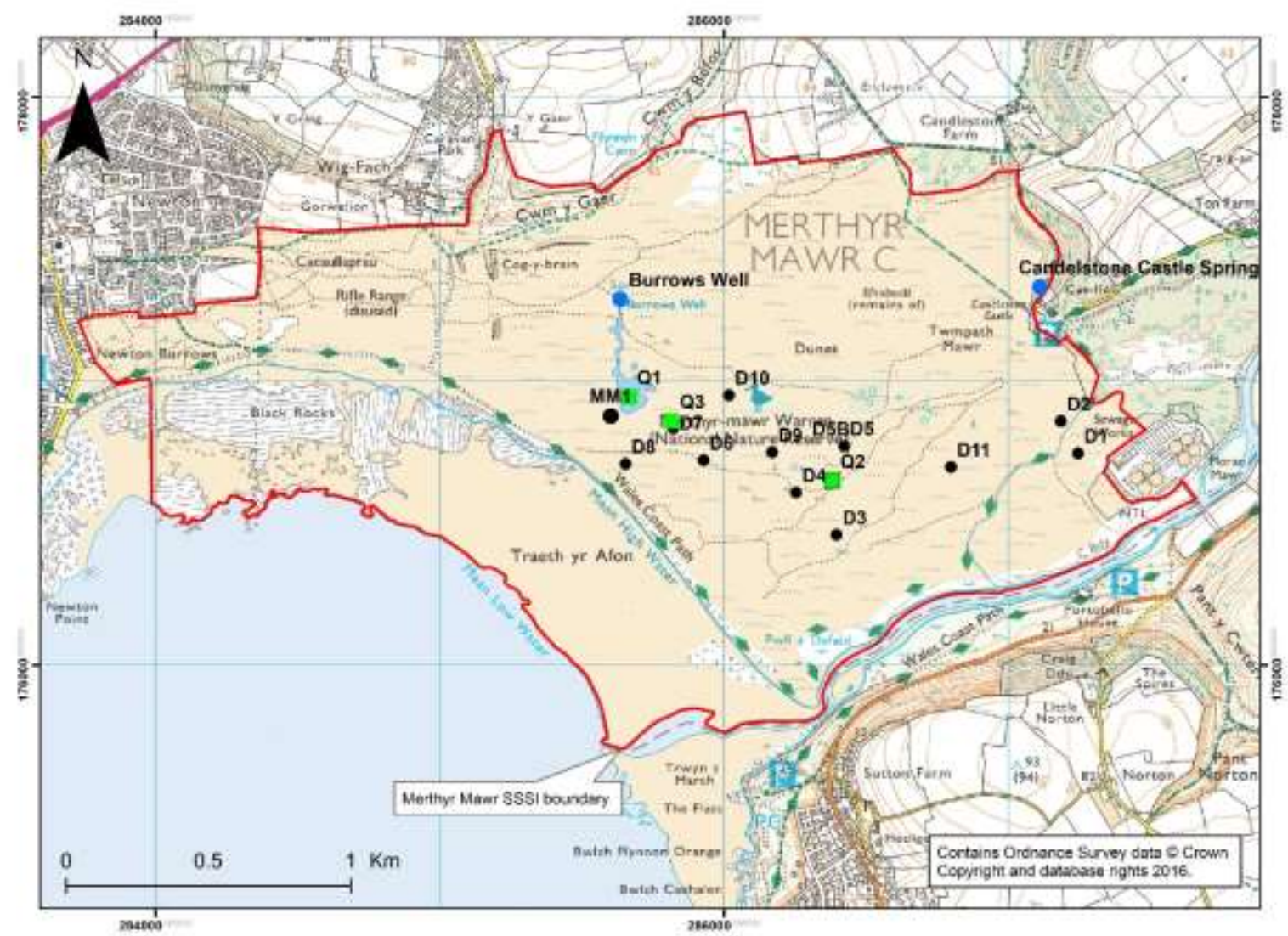

Figure 3: Merthyr Mawr SSSI. Site boundary (red line) and monitoring point including; dipwells D1-11, borehole MM1 and quadrats Q1-3, the slack created from groundwater discharge at the ephemeral spring 'Burrows Well' is outlined in blue. 


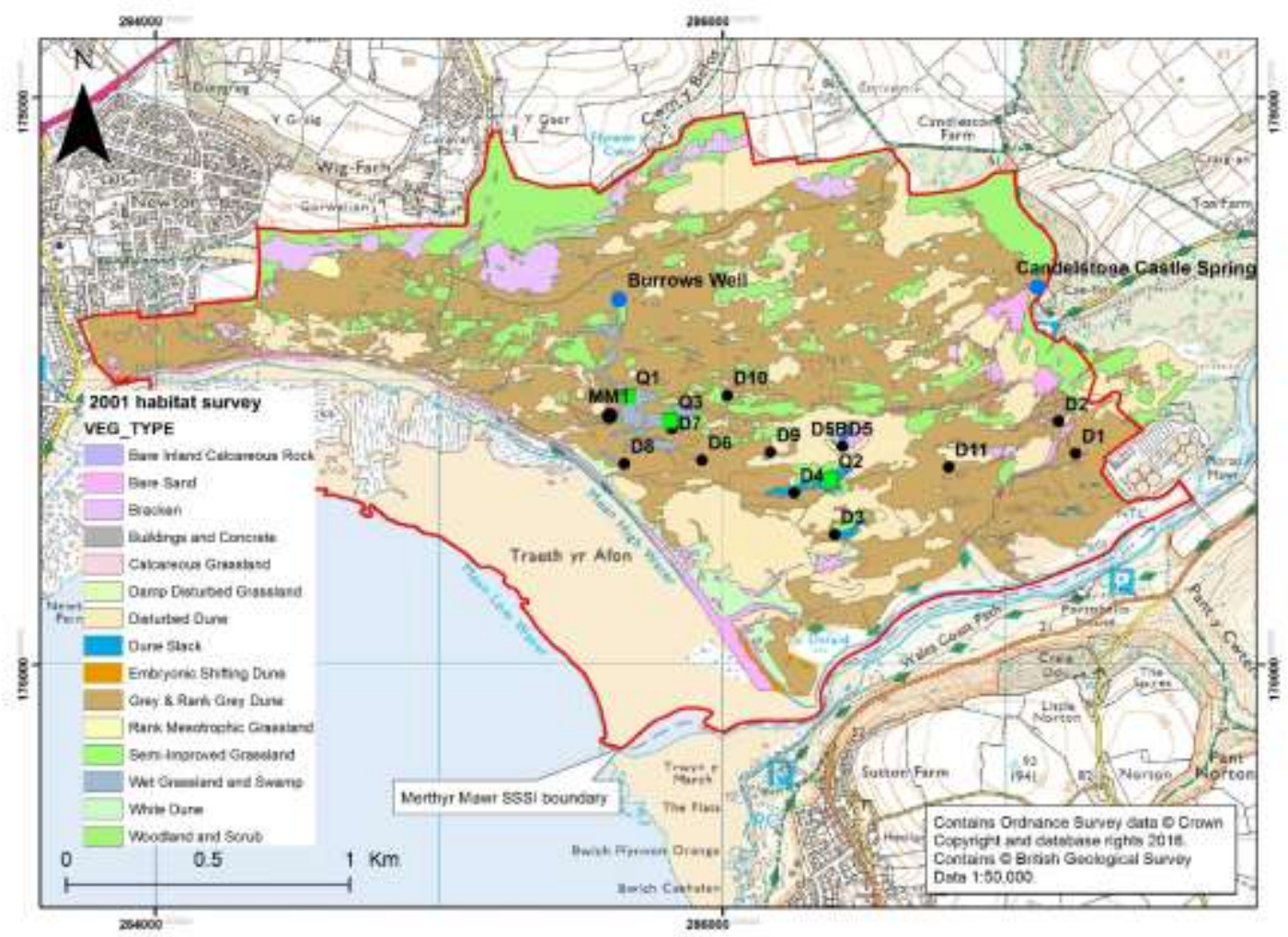

Figure 4. Merthyr Mawr simplified habitat survey with groundwater monitoring locations (Natural Resources Wales, 2001). 


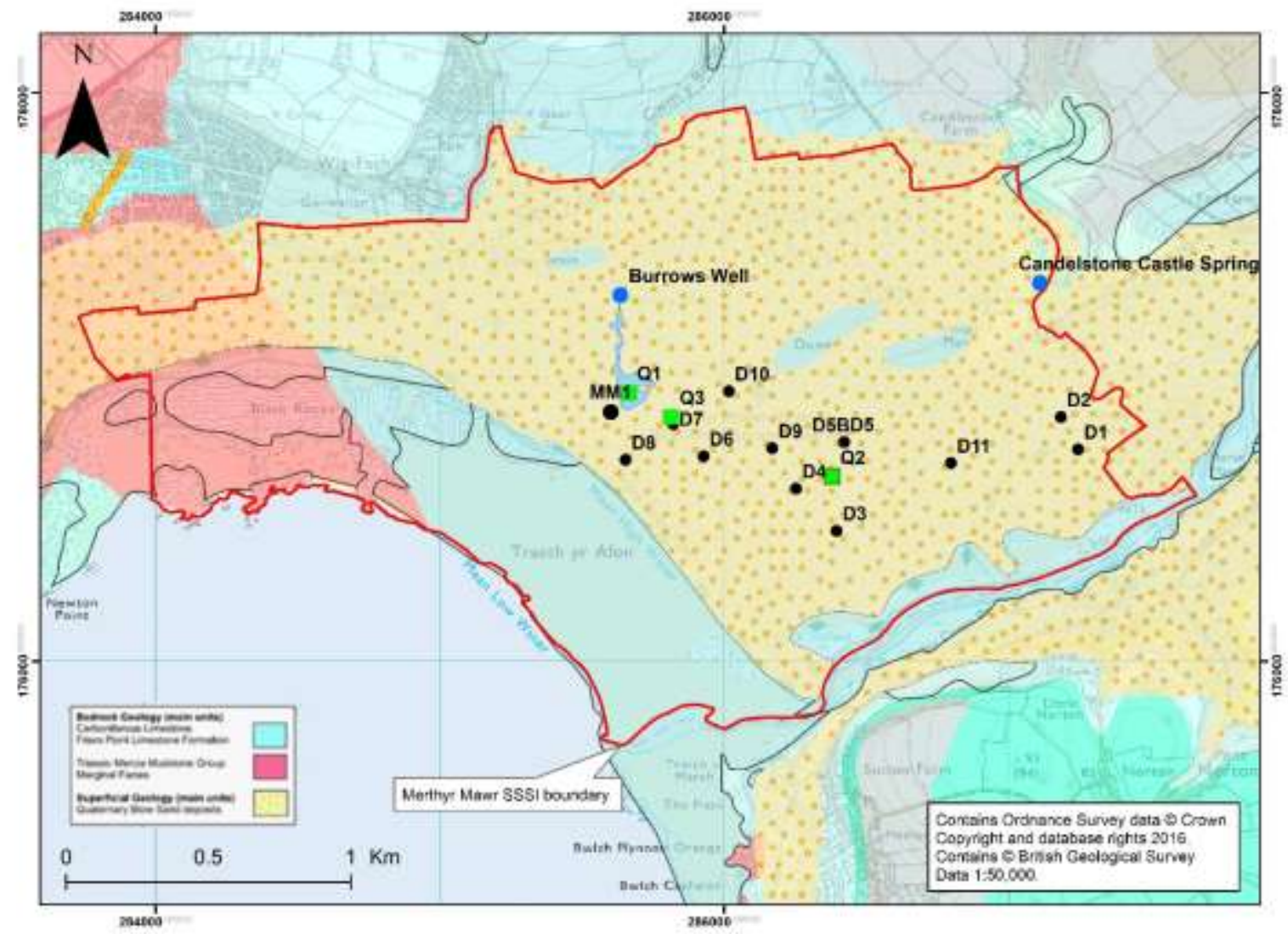

Figure 5: Merthyr Mawr Bedrock and Superficial Geology (British Geological Survey, 1:50,000 Bedrock with 1:50,000 Superficial shown for Blown Sand only) 


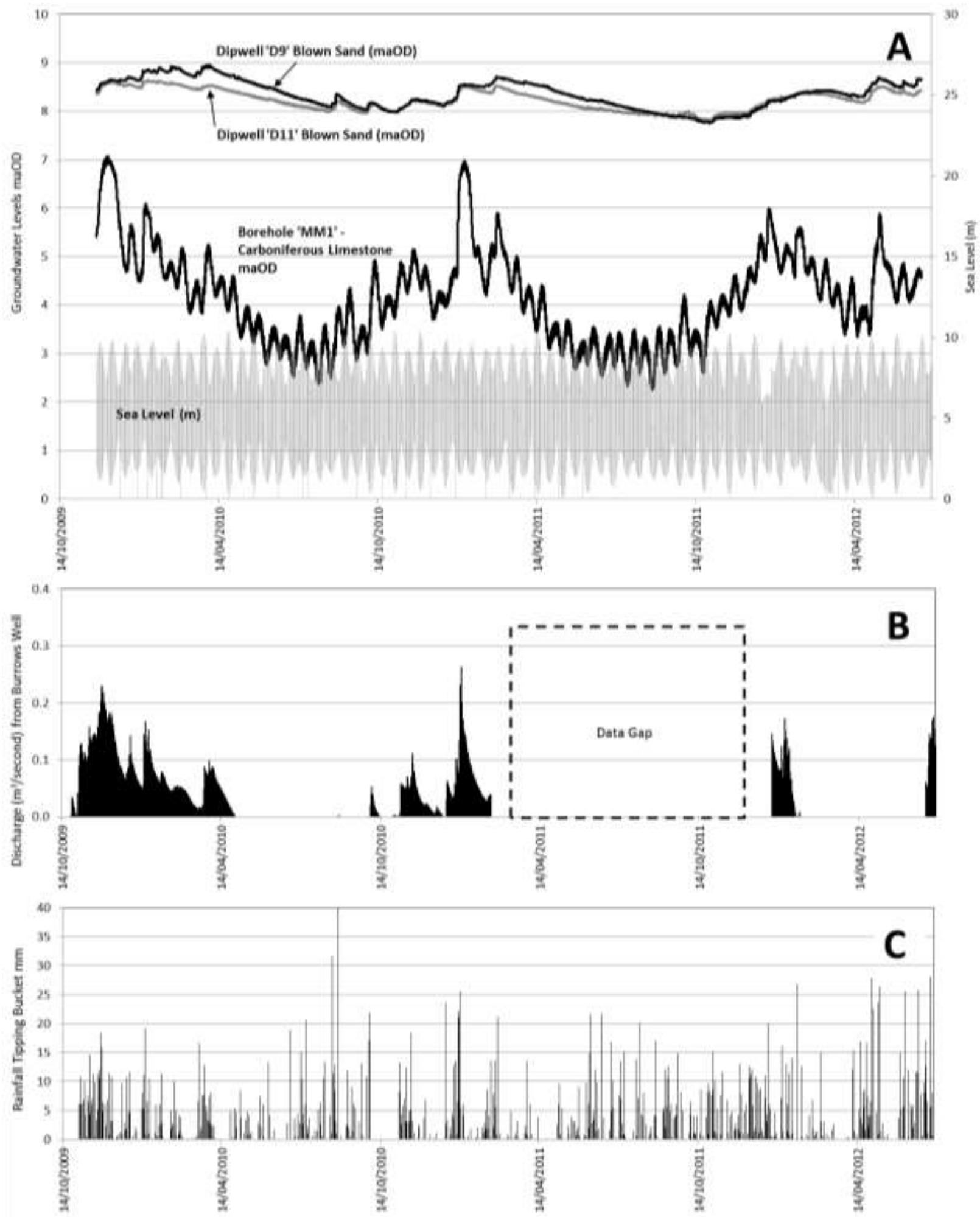

Figure 6A-C. A: Groundwater levels in the Carboniferous Limestone and Blown Sands (data Natural Resources Wales) compared to Tide Level data from Mumbles Tidal Station (British Oceanographic Data Centre) B: Discharge at Burrows Well (Tarmac / ESI Ltd) and C: Rainfall tipping bucket at Schwyll Pumping Station (Natural Resources, Wales Environmental Change Network). 


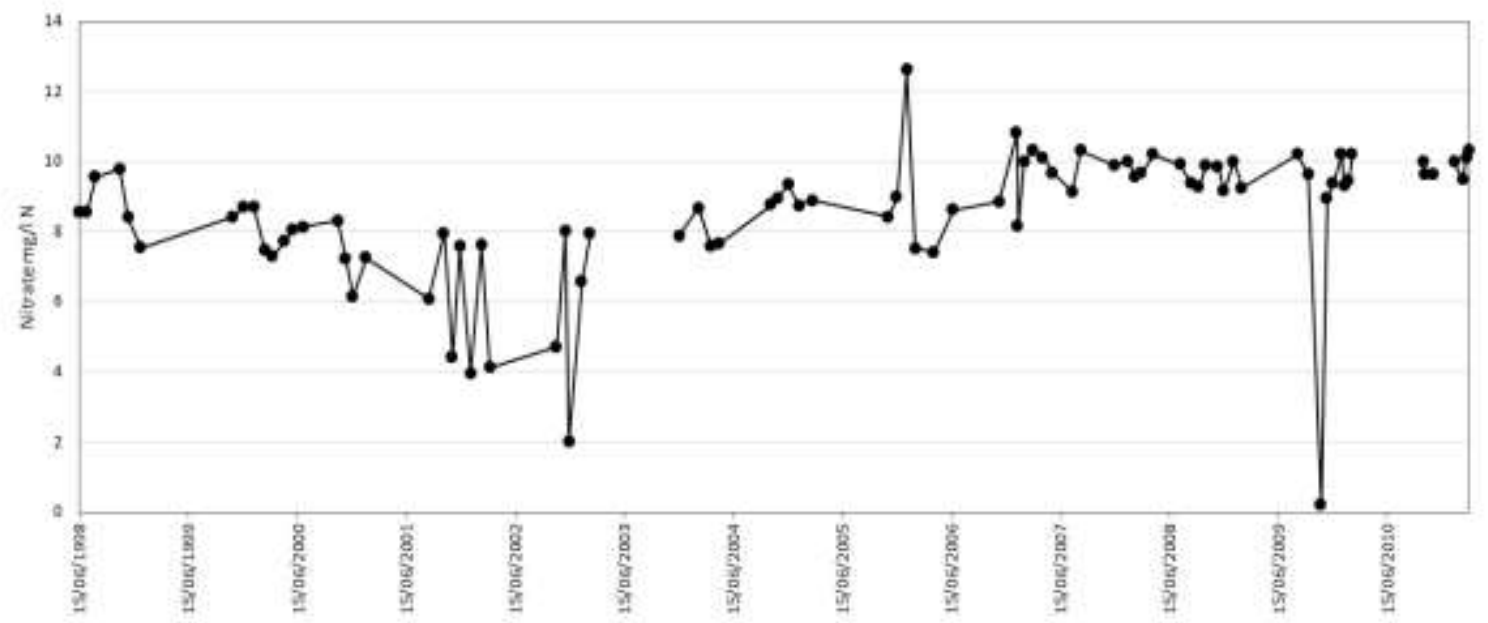

Figure 7: Nitrate N mg/l concentrations from the outflow at Burrows Well (1998-2010), Natural Resources Wales. 


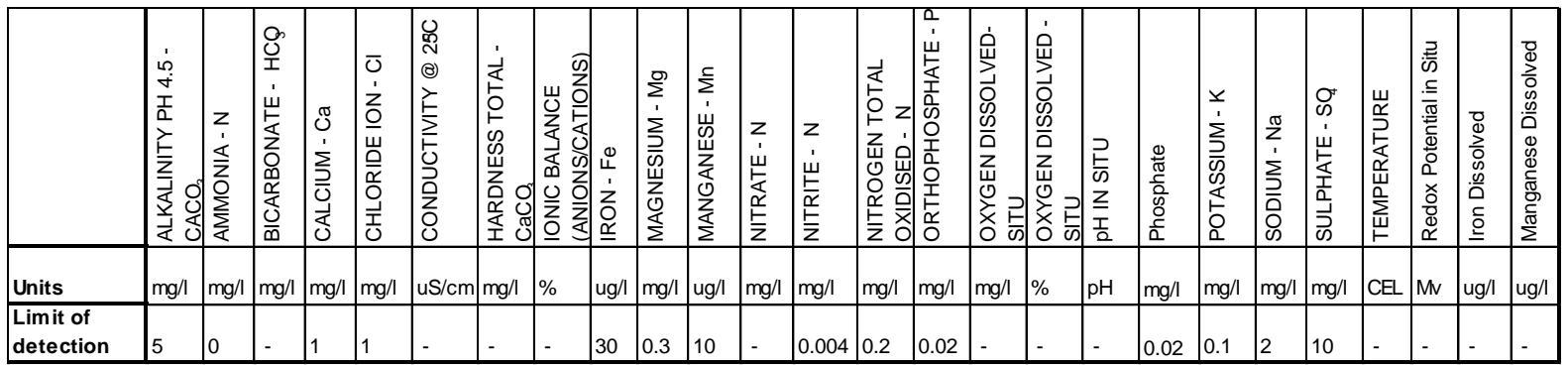

Table 1. Groundwater analysis suite used for Water Framework Directive investigations at humid dunes in England and Wales (from Farr et al. 2014).

\begin{tabular}{|c|c|c|c|c|c|c|c|c|c|c|c|}
\hline Location & Aquifer & Date & $\begin{array}{l}\text { Nitrate } \\
\text { as N }\end{array}$ & $\begin{array}{l}\text { Total } \\
\mathbf{P}\end{array}$ & $\mathrm{Ca}^{2+}$ & $\mathbf{M g}^{2+}$ & $\mathrm{Na}^{+}$ & $\mathbf{K}^{+}$ & $\mathrm{HCO}_{3}{ }^{2-}$ & $\mathrm{Cl}^{-}$ & $\mathrm{SO}_{4}{ }^{2-}$ \\
\hline Borehole MM1 & Limestone & $11 / 01 / 2010$ & 8.29 & $<.02$ & 164 & 10.6 & 21.1 & 2.57 & 383 & 33.2 & 16 \\
\hline Borehole MM1 & Limestone & $05 / 02 / 2010$ & 7.87 & $<.02$ & 133 & 10.2 & 19 & 2.36 & 362 & 33.7 & 15 \\
\hline Borehole MM1 & Limestone & $10 / 06 / 2010$ & 9.07 & $<.02$ & 201 & 13.9 & 18.5 & 2.52 & 390 & 36.2 & 15.4 \\
\hline Borehole MM1 & Limestone & $14 / 10 / 2010$ & 8.92 & $<.02$ & 131 & 10.1 & 17.9 & 2.09 & 376 & 32.8 & 15.6 \\
\hline Burrows Well & Limestone & $11 / 01 / 2010$ & 10.2 & 0.023 & 130 & 8.81 & 18.4 & 2.19 & 388 & 33.4 & 16 \\
\hline Burrows Well & Limestone & $05 / 02 / 2010$ & 9.46 & $<.02$ & 129 & 8.6 & 18.1 & 2.19 & 366 & 33.5 & 15 \\
\hline Burrows Well & Limestone & $14 / 10 / 2010$ & 9.98 & $<.02$ & 130 & 9.54 & 17.4 & 2.03 & 361 & 33.3 & 15.8 \\
\hline Burrows Well & Limestone & $19 / 10 / 2010$ & 9.63 & $<.02$ & 131 & 9.6 & 17.7 & 2.02 & 364 & 33.1 & 16 \\
\hline Burrows Well & Limestone & $17 / 11 / 2010$ & 9.62 & $<.02$ & 130 & 8.87 & 17.3 & 2.01 & 360 & 32 & 15.2 \\
\hline Burrows Well & Limestone & $26 / 01 / 2011$ & 9.98 & $<.02$ & 129 & 8.37 & 18.2 & 2.2 & 375 & 32.9 & 15.9 \\
\hline Burrows Well & Limestone & $24 / 02 / 2011$ & 9.47 & $<.02$ & 127 & 8.55 & 17.4 & 1.97 & 356 & 29.7 & 14.4 \\
\hline Burrows Well & Limestone & $07 / 03 / 2011$ & 10.1 & $<.02$ & 128 & 8.79 & 18.4 & 2.09 & 375 & 32.8 & 15.9 \\
\hline Burrows Well & Limestone & $16 / 03 / 2011$ & 10.3 & $<.02$ & 130 & 8.94 & 18.7 & 1.94 & 378 & 33.8 & 15.8 \\
\hline Dipwell D4 & Blown Sand & $04 / 11 / 2009$ & 2.28 & $<.02$ & 306 & 17.3 & 53.1 & 5.5 & 315 & 73.9 & 20 \\
\hline Dipwell D4 & Blown Sand & $10 / 06 / 2010$ & $<.196$ & $<.02$ & 136 & 5.82 & 12.9 & 1.34 & 388 & 25.6 & 5 \\
\hline Dipwell D4 & Blown Sand & $14 / 10 / 2010$ & $<.196$ & $<.02$ & 119 & 5.37 & 11.3 & 1.43 & 299 & 33.4 & 5 \\
\hline Dipwell D4 & Blown Sand & $07 / 03 / 2011$ & $<.196$ & $<.02$ & 108 & 4.83 & 12.6 & 0.949 & 310 & 23.9 & 5 \\
\hline Dipwell D6 & Blown Sand & $04 / 11 / 2009$ & 8.67 & $<.02$ & 138 & 8.91 & 16.9 & 2.11 & 377 & 30 & 15 \\
\hline Dipwell D6 & Blown Sand & $14 / 10 / 2010$ & $<.196$ & $<.02$ & 134 & 5.33 & 35.2 & 1.86 & 317 & 68.7 & 28.3 \\
\hline Dipwell D9 & Blown Sand & $04 / 11 / 2009$ & $<.196$ & $<.02$ & 121 & 4.76 & 16.2 & 1.11 & 364 & 20.8 & 5 \\
\hline Dipwell D9 & Blown Sand & $05 / 02 / 2010$ & 2.01 & $<.02$ & 116 & 6.83 & 34.8 & 1.84 & 235 & 48.9 & 11 \\
\hline Dipwell D9 & Blown Sand & $10 / 06 / 2010$ & 2.22 & $<.02$ & 127 & 8.05 & 59.8 & 1.57 & 292 & 112 & 19.3 \\
\hline Dipwell D9 & Blown Sand & $14 / 10 / 2010$ & 2.55 & $<.02$ & 122 & 7.53 & 43.6 & 1.61 & 264 & 70.9 & 13.4 \\
\hline Dipwell D9 & Blown Sand & $07 / 03 / 2011$ & 0.586 & $<.02$ & 108 & 6.75 & 39.1 & 1.44 & 239 & 60.3 & 13.3 \\
\hline
\end{tabular}

Table 2. Groundwater chemistry from the Carboniferous Limestone and blown sand aquifers (all units $\mathrm{mg} / \mathrm{l}$, data from Natural Resources Wales). 
